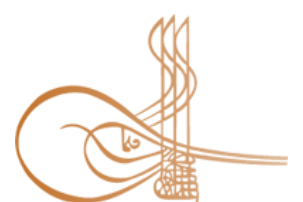

www.turkishstudies.net/economy
Turkish Studies - Economics, Finance, Politics

eISSN: $2667-5625$

Research Article / Araștırma Makalesi

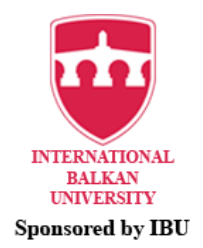

Sponsored by IBU

\title{
Entegre Raporlamanın Tarihsel Gelişimi ve Literatür Çalışması ${ }^{*}$
}

The Historical Development of Integrated Reporting and a Literature Review

\author{
Ahmet Akbaş $^{* *}$ - Ali Çoskun ${ }^{* * *}$ - Osman Karamustafa ${ }^{* * * *}$
}

\begin{abstract}
Financial statements, which started to be published with the industrial revolution, began to change in accordance with the demands of capital markets and also with the current and the potential investors' requests and desires. These requests, desires and demands have led to significant changes in financial statements, but these did not completely meet the expectations of investors. Non-financial reports, which have started to be published especially with the spread of corporate governance, have significantly contributed to meeting their expectations. Thus, non-financial and financial performances of a given company are very important in the new period. Accordingly, they also have a considerable amount of influence on investment decisions of investors. Moreover, the increasing importance of non-financial information has brought about changes in most of the companies. In this context, the need for a new type of reporting has emerged. The present study provides a definition of integrated reporting which is a new type of reporting that involves financial and non-financial information. It also briefly presents the course of the development of integrated reporting in the world, and in particular, in Turkey. Moreover, it introduces studies on integrated reporting under three categories. It reveals that a significant number of these works focus on conceptualization and contents analyses. In this regard, studying these works demonstrate that the integrated reporting still has not reached to its maturity. Additionally, since the number of integrated reporting published in Turkey is very few, the studies are limited. For this reason, the increase of integrated reports published in the future will make it easier to obtain reliable findings for studies.
\end{abstract}

Structured Abstract: Financial statements, which started to be published with the industrial revolution, began to change in accordance with the demands of capital markets and also with the current and the potential

\footnotetext{
* Bu çalışma Recep Tayyip Erdoğan Üniversitesi Sosyal Bilimler Enstitüsü’nde devam etmekte olan "Entegre Raporlamanın İç Değişim Mekanizması ve Yatırımcı Kararları Üzerindeki Etkisi” konulu doktora tez çalışmasından türetilmiştir.

** Araştırma Görevlisi, Recep Tayyip Erdoğan Üniversitesi, İktisadi ve İdari Bilimler Fakültesi, İşletme Bölümü Research Assistant, Faculty of Economics, Administrative and Social Sciences, Department of Business ORCID 0000-0002-1947-8181

ahmet.akbas@erdogan.edu.tr

**** Dr. Öğr. Üyesi, Boğaziçi Üniversitesi, İİBF, İşletme Bölümü

Asst. Prof. Dr., Boğaziçi University, Faculty of Economics, Administrative and Social Sciences, Department of Management

ORCID 0000-0003-1723-1107

ali.coskun@boun.edu.tr

${ }_{* * * * *}$ Prof. Dr, Recep Tayyip Erdoğan Üniversitesi, İktisadi ve İdari Bilimler Fakültesi, İşletme Bölümü

Prof. Dr., Faculty of Economics, Administrative and Social Sciences, Department of Business

ORCID 0000-0002-0935-1830

okaramustafa@erdogan.edu.tr

Cite as/ Atıf: Akbaş, A., Çoskun, A. \& Karamustafa, O. (2020). Entegre raporlamanın tarihsel gelişimi ve literatür çalışması. Turkish Studies - Economy, 15(3), 1103-1121. https://dx.doi.org/10.47644/TurkishStudies.44198

Received/Geliş: 12 June/Haziran 2020

Accepted/Kabul: 20 September/Eylül 2020

Copyright $(\mathrm{C}$ INTAC LTD, Turkey

Checked by plagiarism software

Published/Yayın: 25 September/Eylül 2020

CC BY-NC 4.0
} 
investors' requests and desires. These requests, desires and demands have led to significant changes in financial statements, but these did not completely meet the expectations of investors. Non-financial reports, which started to be published especially with the spread of corporate governance, have made significant contributions to meeting their expectations. Thus, the need for a new type of reporting has emerged.

After South Africa adopted the democratic management approach in 1994, a working committee was formed by Mervyn King in order to reduce the existing distrust in the South African market and increase the trust in companies with the support of Nelson Mandela. After the release of KING reports, the importance of transparent financial and non-financial information has been explained, and firms were encouraged to publish integrated reporting. Soon after, integrated reporting became legally compulsory for all companies operating in South Africa, and they were required to prepare reports with the understanding of "report or explain" (Aras \& Sarığlu, 2015, s. 41).

One of the first definitions of integrated reporting in the literature is made in the KING III Report as follows: "It is a holistic and integrated representation of the company performance in terms of both financial and non-financial information" (KING III, 2009, p.108). IIRC also define it, as "a concise communication about how an organization's strategy, governance, performance and prospects, in the context of its external environment, lead to the creation of value over the short, medium and long term "(IIRC,2013, sf:7). It is believed that integrated reporting, which brings a new approach to reporting and important changes to the reporting process, will become an important part of the corporate governance.

Considering the historical development of integrated reporting, the first studies started appear in the early 1970s. Infact, in a 1970 report titled "The Corporate Report" published by the UK Accounting Standards Steering Committee, it is stated that the information in the corporate report should be prepared not only with the perspective of shareholders and managers but also by considering the needs of all stakeholders. Although this report is not fully expressed as an integrated reporting study, it can be regarded as one of the first studies on this matter because it aims to prepare reports by taking into account the requests and demands of the all stakeholders.

Eccles and Krsuz (2015) stated that the integrated reporting development process consists of four stages. The first stage is Company Experimentation, the second stage is Expert Commentary, the third stage is Codification and the final stage is institutionalization. In addition to these stages prepared by Eccles, a new type of stage called the "pioneering" stage has been added. KING I, KING II and the "Corporate Report" are considered to be pioneering stages in this regard.

Since integrated reporting is a new type of reporting, although the studies are generally conceptual in nature, there are many qualitative studies as well as a small number of quantitative studies. In line with this, the studies in the relevant scholarship will be analyzed here under three separate groups as conceptual, quantitative and qualitative studies. When one examines the conceptual studies, one realizes that most of these can be characterized as works that attempt to study such topics as "the quiddity of integrated reporting", "its historical development", "literature review on it" and "its benefits and problems". A close examination of the qualitative studies reveals that most of these are content analysis studies. Finally, when the quantitative studies are examined, it can be seen that their number is limited compared to the number of conceptual and qualitative studies.

The present study provides a definition of integrated reporting which is a new type of reporting that involves financial and non-financial information. It also briefly presents the course of the development of integrated reporting in the world, and in particular, in Turkey. Moreover, it introduces studies on integrated reporting under three categories. It reveals that a significant number of these works focus on conceptualization and contents analyses. In this regard, studying these works demonstrate that the integrated reporting still has not reached to its maturity.

Keywords: Accounting, Integrated Reporting, One Report, Non-Financial Reporting

Öz: Sanayi devrimi ile birlikte yayınlanmaya başlayan finansal tablolar, ilerleyen dönemlerde sermaye piyasalarının ve mevcut ve potansiyel yatırımcıların istek ve talepleri doğrultusunda değişmeye başlamıştır. $\mathrm{Bu}$ istek ve talepler finansal tablolarda önemli değişikliklere sebep olmuş, fakat tam anlamıyla yatırımcıların beklentilerini karşılamamıştır. Özellikle kurumsal yönetim anlayışının yaygınlaşması ile birlikte, finansal 
olmayan bilgiye olan talebin artması, yatırımcı beklentilerinin karşılanması noktasında ciddi katkılar sağlamıştır. Böylece, şirketlerin finansal performansının yanında, finansal olmayan performansının da önem kazandığı ve yatırım kararları üzerinde etkili olduğu bir döneme geçilmeye başlanmıştır. Finansal olmayan performansın artan ehemmiyeti, şirketlerde de bir değişimi beraberinde getirmiştir. Böylelikle, yeni bir raporlama türüne olan ihtiyaç ortaya çıkmıştır. Bu çalışmada, finansal ve finansal olmayan bilginin yer aldığı yeni bir raporlama türü olan entegre raporlamanın tanımı yapılmış, kısaca dünya ve Türkiye'deki tarihsel gelişimine de yer verilmiştir. Ayrıca, entegre raporlama üzerine yapılan çalışmalar üç başlık altında tanıtılmış, çalışmaların önemli bir kısmının kavramsal çalışmalar ve içerik analizleri; nicel çalışmaların ise daha az sayıda olduğu görülmüştür. Bu bağlamda, çalışmalar incelendiğinde entegre raporlamanın hala gelişim aşamasında olduğu tespit edilmiştir. Ayrıca, Türkiye'de yayınlanan entegre rapor sayısı az olduğu için, yapılan çalışmalar sınırlı kalmaktadır. Bu sebepten dolayı, ilerleyen dönemlerde yayınlanan entegre raporlama sayısındaki artış, çalışmalar için daha sağlıklı sonuçlar elde edilmesini kolaylaştıracaktır.

Anahtar Kelimeler: Muhasebe, Entegre Raporlama, Tek Rapor, Finansal Olmayan Raporlama

\section{Giriş}

Sanayi devrimi sonrasında yayımlanmaya başlayan finansal tablolar, ilerleyen dönemlerde çıar gruplarının istek ve talepleri doğrultusunda değişmeye başlamıştır. Bu istek ve talepler klasik finansal tablolarda ciddi değişikliklere sebep olmuş, fakat tam anlamıla bilgi kullanıcılarının beklentilerini karşılamamıştır. Özellikle kurumsal yönetim anlayışının gelişmiş ve gelişmekte olan ülkelerde yaygınlaşması ve finansal olmayan bilgiye olan talebin artması, finansal olmayan raporlama türlerinin şirketler tarafından yayımlanmasına sebep olmuş, bu durum da yatırımcı istek ve taleplerinin karşılanması noktasında katkılar sağlamıştır. Böylece, şirketlerin finansal performansının yanında, finansal olmayan performansının da önem kazandığı bir döneme geçilmeye başlanmıştır.

Finansal tablolar, endüstri devriminden sonra uzun yıllar şirket performansının değerlendirilmesinde tek kaynak iken (Aras \& Sarığlu, 2015), daha sonra yaşanan siyasi ve ekonomik krizler, şirket skandalları ve çevresel problemler gibi etkenler finansal tabloların işletmenin performansını ortaya koymada yetersiz kaldığını ortaya çıkarmıştır. Finansal tablolarda yer alan finansal bilginin yetersiz kalması, özellikle 1950'li yıllardan sonra yeni raporlama türlerinin ortaya çıkmasına sebep olmuştur. 2000 sonrası dönemde ise, uluslararası şirketlerin hazırlamış olduğu finansal tablolarda muhasebe hilelerinin ortaya çıkmasıyla başlayan şirket skandalları, gelişmiş ülkeler başta olmak üzere ülkelerde finansal krizlerin belirleyici argümanı olmuştur. Yaşanan bu skandallar, işletmelerin ekonomik performansını sunan finansal raporların tartışılmasına sebep olmuş ve çıkar grupları tarafindan klasik finansal tablolar daha fazla sorgulanmaya başlanmıştır. Yatırımcılar, finansal raporlar ile işletmenin tam anlamıyla finansal performansını ve aynı zamanda değer yaratma kabiliyetini değerlendirmekte zorlanmıştır. Daha önceki dönemlerde yayımlanan finansal olmayan raporlar, işletmenin finansal olmayan performansı hakkında bilgiler sağlasa da bu raporların denetiminin ve güvencesinin makul seviyede olmaması, belli bir standardının olmayışı gibi bazı sebeplerden dolayı yeni bir raporlama sunumuna olan ihtiyacı ortaya çıkarmıştır.

Güney Afrika'nın 1994 yılında demokratik yönetim anlayışını benimsemesinden sonra, Nelson Mandela'nın desteğiyle piyasalarda var olan güvensizliği azaltmak ve firmalara olan güveni artırmak amacıyla, Mervyn King tarafından bir çalışma komitesi oluşturulmuştur. 1994 yılında, KING I olarak adlandırılan ilk rapor hazırlanmış, daha sonra ise 2002 yılında KING II ve 2010 yılında da KING III raporları yayımlanmıştır. Yayımlanan KING I ve KING II raporlarından sonra net ve şeffaf bilgi paylaşımının önemi anlatılarak, işletmelerin entegre raporlama sunması teşvik edilmiştir. KING III raporundan sonra ise, Güney Afrika'da faaliyet gösteren ve aynı zamanda borsaya kote olan tüm şirketlerin "raporla ya da açıkla" anlayışı ile rapor hazırlaması yasal olarak zorunlu hale getirilmiştir (Aras \& Sarıoğlu, 2015, s. 41). Bu yasal zorunluluk sonrasında, başta 
Güney Afrika olmak üzere, gelişmiş ülkeler ve birçok farklı ülkede entegre raporlama yayımlanmaya başlamıştır.

İlk olarak Güney Afrika'da yayımlanan entegre raporlama, finansal bilgi kullanıcılarının kararlarını verirken işletmelerin klasik finansal tablolarda sunduğu finansal bilgilerin ötesine geçmesine yardımcı olan ve finansal olmayan bilgilere de dikkat çekmesini sağlayan bir raporlama türüdür (IIRC, 2013). Entegre raporlama, finansal ve finansal olmayan bilginin sadece bir araya getirildiği bütünleşik raporlamanın ötesinde bir kavramdır. İşletmenin kısa, orta ve uzun vadedeki planlarının, stratejilerinin, kurumsal yönetişim hakkındaki bilgilerin paylaşıldığı ve aynı zamanda işletme faaliyetlerinin sosyal, çevresel ve ekonomik bağlamını gösterecek şekilde finansal ve finansal olmayan bilgilerin sebep-sonuç ilişkisi içerisinde kısa ve öz bir şekilde sunulduğu bir raporlama türüdür. Özellikle yatırımcıların işletmenin performansını sağlıklı bir şekilde değerlendirip, doğru bir yatırım kararı verebilmesi için işletmenin finansal tablolarına ek olarak, sürdürülebilirlik, çevresel ve sosyal sorumluluk raporlarında sunulan ve yatırımcı kararları için oldukça önemli olan bilgileri içeren bir raporlamadır.

Bu çalışmada, birçok uluslararası şirket tarafindan yayımlanan ve aynı zamanda kurumsal yönetim anlayışııın raporlama türü olarak görülen entegre raporlama kavramının öncelikle tanımı yapıldıktan sonra, dünyada ve Türkiye'deki tarihsel gelişimine yer verilmiş ve son olarak ulusal ve uluslararası bazı çalışmalar kısaca tanıtılmıştır. Yeni bir raporlama türü olan entegre raporlama üzerine yapılan çalışmaların incelendiği ve kapsamlı bir şekilde tarihsel gelişimin anlatıldığı bu çalışmanın literatüre katkı sağlayacağı düşünülmektedir.

\section{Entegre Raporlama Kavramı ve Tanımı}

Finansal raporlar yatırımcılar için kurumsal raporlamanın önemli unsuru olarak kabul edilmektedir (Eccles ve Spiesshofer, 2015). İ̧̧letmenin finansal durumunu ve faaliyet sonuçlarına ait finansal bilgileri çıkar gruplarına sunmak için hazırlanan finansal raporlar, tüm paydaşların çıkarları gözetilmeden hazırlanmaktadır. Özellikle kurumsal yönetim anlayışının gelişmesiyle birlikte popüler olmaya başlayan finansal olmayan raporlama türleri, tüm paydaşların çıkarlarını dikkate almaya başlamıştır. Bu bağlamda, entegre raporlama bu raporlama türlerinde yer almayan tüm finansal ve finansal olmayan bilgileri aynı rapor içinde çıkar gruplarına sağlamaktadır.

Teknolojide yaşanan hızlı gelişmeler, firmaların bilgi kullanıcılarına daha fazla sorumluluk bilinciyle veri sunma gereğini ortaya çıkarmış, fakat işletmenin sosyal, çevresel ve yönetişimsel faaliyetleri ile ilgili bilgiler sunan finansal olmayan raporlama türleri, çıkar gruplarının hala önem verdiği finansal bilgileri içermemektedir. Uluslararası piyasada hızlı sermaye hareketlerinin olduğu bir dönemde, finansal ve finansal olmayan bilgilerin ayrı olarak sunulması yatırımcı kararları için yeterli olmamaktadır. Bu dönemde, klasik finansal tablolar çıkar gruplarının ihtiyaç duyduğu bilgileri tam olarak sağlamaması; finansal olmayan raporlamada ise, yatırımcıların hala önem verdiği finansal performansın yer almaması, finansal bilgilerin yanında finansal olmayan bilgileri içerisinde barındıran entegre raporlama kavramının doğmasına sebep olmuştur. Kurumsal raporlamanın yeni raporlama türü olan entegre raporlama, yatırımcıların beklentileri doğrultusunda son birkaç yıl içinde gelişmeye başlamıştır.

Literatürde, entegre raporlama farklı şekillerde adlandırılmıştır. Eccles ve Krzus (2010) tarafindan ilk kez tek rapor (One Report) olarak adlandırılan entegre raporlama, daha sonraki ulusal çalışmalara bakıldığında "tümleşik rapor", "bütünleşik rapor” gibi isimlerle adlandırılmasına rağmen, tam olarak tümleşik ve bütünleşik kavramları ile açıklanamadığı için "entegre raporlama" olarak literatürde yer almıştır.

Literatürde entegre raporlamanın ilk tanımlarından biri KING III Raporunda şu şekilde yapılmıştır: Şirket performansının hem finansman hem de sürdürülebilirliği açısından bütünsel ve bütünleşik bir temsilidir (KING III, 2009, s. 108). King IV raporunda ise, bir işletmenin zaman içinde 
değer yaratma konusunda periyodik bir raporlama ile sonuçlanan entegre düşünceye dayalı bir süreç olarak ifade edilmiştir (KING IV, 2016, s. 13).

Eccles ve Kurz (2010) entegre raporlamayı, işletmenin yıllık faaliyet raporunda yer alan finansal ve finansal olmayan (çevresel, sosyal ve yönetişim gibi) bilgileri ve işletmenin kurumsal sosyal sorumluluk veya sürdürülebilirlik raporları içerisinde yer alan bilgileriyle birleştiren tek bir rapor olarak tanımlamıştır. Entegre raporlamanın içinde farklı çıkar gruplarına yönelik bilgilerin yer aldığını ve tüm bilgilerin entegre edilmesinin, bütünleşik bir raporun hazırlanmasından çok daha fazlası olduğunu belirtmiştir. Ek olarak, Eccles ve Kurz, tek raporun sadece tek bir rapor anlamına gelmediğini vurgulamış, işletmenin temel finansal ve finansal olmayan bilgilerini birleştiren bir rapor olması ve şirketin belirli çıkar gruplarını hedef alan bilgilerden daha ziyade tüm çıkar gruplarını ilgilendiren bilgileri sağlaması gerektiğini belirtmiştir.

KPMG tarafindan hazırlanan raporda, işletmenin stratejisini, iş modelini ve faaliyet gösterdiği alanlarla ilgili bilgileri tarihi performans ile sunan, aynı zamanda şirketin performans ölçütlerine ulaşması konusunda karşı karşıya kalabileceği riskleri açıklayan, kısa, orta ve uzun vadede sürdürülebilirliği nasıl sağlayacağını çıkar gruplarına aktaran bir raporlama türü olarak tanımlanmıştır (KPMG, 2011, s. 2).

Uluslararası Entegre Raporlama Konseyi'ne göre entegre raporlama (IIRC, 2013a, s. 7); “Bir kuruluşun içinde yer aldı̆̆ dış çevre bağlamında stratejisi, yönetimi, performansı ve gelecekten beklentilerinin kısa, orta ve uzun vadede nasıl değer yarattı̆̆ının kısa ve öz bir iletişimidir". Borsa İstanbul tarafından hazırlanan rehberde (Borsa İstanbul, 2014, s. 35), entegre raporlama işletmenin gelecekteki stratejisini, yönetim ve finansal performansı ile faaliyet gösterdiği alandaki çevresel, sosyal ve ekonomik faktörler arasındaki bağlantıyı tanımlar.

Yukarıdaki tanımlara ek olarak, Ayoola ve Olasanmi (2013) entegre raporlamayı, daha sürdürülebilir bir küresel ekonomiye ulaşmak için, bir işletmenin performansı ve ülkeye etkisi hakkındaki bilgileri bir araya getiren bir raporlama olarak tanımlamış, Abeysekera (2014) ise, entegre raporlamayı, çok boyutlu kaynaklar kullanarak kuruluşun uzun vadeli vizyonuna ve stratejisine ulaşma konusundaki performansının sunulması olarak ifade etmiştir.

$\mathrm{Bu}$ bağlamda, entegre raporlama işletmenin klasik finansal raporlarda yer alan finansal bilgileri ve finansal olmayan raporlama türlerinde yer alan finansal olmayan bilgileri birbiriyle bağlantılı olarak ortaya koyan, işletmenin nasıl değer yarattığını ve bu sosyal, çevresel ve ekonomik değeri kısa, orta ve uzun vadede nasıl sürdürülebilir kılacağının kısa ve öz olarak anlatımı olarak ifade edilebilir.

Entegre raporlama günümüzde birçok değişikliğe veya gelişmeye neden olmuştur. Faaliyet odakl11 ğg yerine stratejik odaklılığa önem veren, kısa vadeli bakış açısı yerine daha uzun vadeli bakış açısına sahip olan, geriye dönük bir analizden ziyade ileriye dönük bir süreç olduğu düşünülen ve niteliksel bir yorum ve niceliksel bilgi sağlayan bir raporlama türüdür (Hertgers, 2016). Raporlamaya yeni bir bakış açısı ve raporlama sürecine önemli değiş̧iklikler getiren entegre raporlamanın kurumsal yönetim anlayışının önemli bir parçası haline geleceği düşünülmektedir.

\section{Entegre Raporlamanın Gelişim Süreci}

Entegre raporlamanın tarihsel gelişimine bakıldığında, ilk çalışmaların 1970'li yılların başında başladığ 1 ve UK Accounting Standards Steering Committee (Birleşik Krallık Muhasebe Standartları Yönlendirme Komitesi) tarafindan yayımlanan "Kurumsal Raporlama" (The Corporate Report) başlığıyla hazırlanan raporda, kurumsal rapor içeriğindeki bilgilerin sadece hissedarların ve yöneticilerin bakış acısıyla değil, tüm çıkar gruplarının ihtiyaçları düşünülerek hazırlanması gerektiği ifade edilmiştir (Köse \& Çetinel, 2017). Hazırlanan bu rapor, tam olarak entegre raporlama çalışması olarak ifade edilmese de, içerik bağlamında entegre raporlamanın temel amaçlarından biri 
olan, raporun tüm paydaşların istek ve talepleri dikkate alınarak hazırlanması amacını taşıdığı için ilk çalışmalardan biri olarak kabul edilebilir.

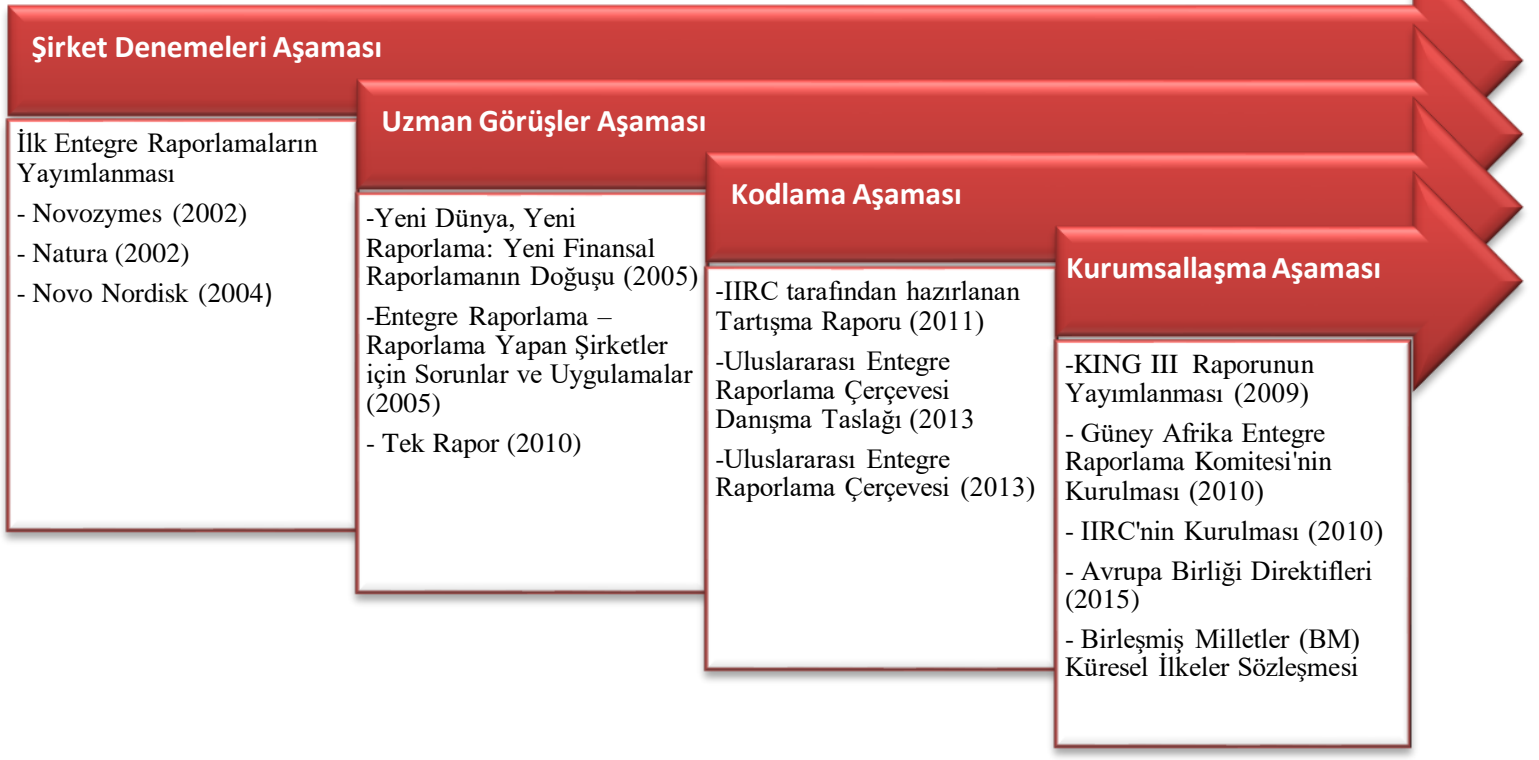

Şekil 1: Entegre Raporlama Aşamaları (Eccles, Krzus, \& Ribot, 2015)

Eccles ve Krsuz (2015) entegre raporlama gelişim sürecinin dört aşamadan oluştuğunu ifade etmiştir. Şekil 1'de görüleceği üzere, ilk aşama şirket denemeleri, ikinci aşama uzman görüşleri, üçüncü aşama kodlama ve son aşama kurumsallaşmadır. Eccles ve Krsuz, Mervyn King öncülüğünde kurumsal yönetim anlayışı çalışmalarını entegre raporlama gelişim süreci içine dahil etmemiştir. Yayımlanan KING I ve KING II raporlanı, aslında tam anlamıyla entegre raporlama çalışması olmamasına rağmen, içerik bağlamında entegre raporlama gelişimine önemli katkılar sağlamıştır. Bu sebepten dolayı, çalışmada gelişim süreci Eccles ve Krsuz'un çalışmasının aksine, beş aşamadan oluşturulmuş, ilk aşama öncü çalışmalar aşaması olarak eklenmiştir.

Entegre raporlama, temelde kurumsal yönetim anlayışı ile birlikte gelişmeye başlamıştır. Kurumsal yönetim anlayışının raporlama türlerinden biri olan entegre raporlama çalışmaları, ilk olarak 1994 yılında, Nelson Mandela'nın destekleriyle, Güney Afrika'daki piyasalara olan güvenin ve şirketlerde hesap verebilirlik ve şeffaflığın artırılması için eski bir yargıç olan Mervyn King öncülüğünde bir çalışma komitesi ile başlamıştır. Komitenin hazırladığı rapor, KING I olarak bilinen "King Raporu: Güney Afrika için Kurumsal Yönetişim- 1994" (King Report On Corporate Governance For South Africa) adıyla Güney Afrika' da faaliyet yürüten şirketlere sunulmuştur (Aras \& Sarığlu, 2015). Hazırlanan raporda, şirketlerin kurumsal yönetim anlayışı ile ilgili etik ve etkili yönetim anlayışının nasıl olması gerektiği paylaşılmıştır. Ayrıca, geniş yelpazedeki paydaşların çıkarlarını dikkate alarak, kurumsal yönetimin mali ve düzenleyici yönlerinin ötesine geçilerek raporlamaya bütünsel bir bakış açısı sağlanması gerektiği ifade edilmiştir. Şirketlerin faaliyet gösterdikleri toplum ve çevreden bağımsız hareket edemeyeceği raporda belirtilmiştir (KING I, 1994).

The Institute of Directors in Southern Africa tarafindan, KING II olarak bilinen "King Raporu: Güney Afrika için Kurumsal Yönetişim- 2002” (KING II, 2002) adlı rapor King 
öncülügünde yayımlamıştır. Yayımlanan bu raporda, kurumsal yönetim anlayışının prensipleri paylaşıldıktan sonra "Entegre Sürdürülebilirlik Raporlaması" (Integrated Sustainability Reporting) başlı̆̆ı altında, Güney Afrika'da faaliyet gösteren şirketlerin finansal olmayan raporları da sunması gerektiği ifade edilmiştir. Bu kapsamda, en az yıllık olarak sosyal, etik, güvenlik, sağlık ve çevre yönetimi politikaları ve uygulamalarının niteliği ve kapsamı hakkında bilgi verilmesi ve yayımlanacak bilgilerin paydaşlarla ilgili olup olmadığına yönetim kurulunu karar vermesi gerektiği belirtilmiştir. Raporun son kısmında şirketler için çeşitli öneriler sunulmuştur. Rapor yayımlandıktan sonra Johannesburg Borsas1 (JSE), borsada faaliyet gösteren şirketlerin hazırlanan KING II raporunda yer alan ilke ve prensiplere nasıl uyduklarını belirtmesi zorunlu kılınmıştır (Aras \& Sarığlu, 2015). Yayımlanan KING I ve KING II raporları, entegre raporlama gelişiminde öncü çalışmalar olarak kabul edilmiş ve Eccles ve Krsuz (2015) tarafından hazırlanan gelişim aşamalarına ek olarak, şekil 2'de görüldüğü gibi, öncü çalışmalar aşaması eklenmiştir.

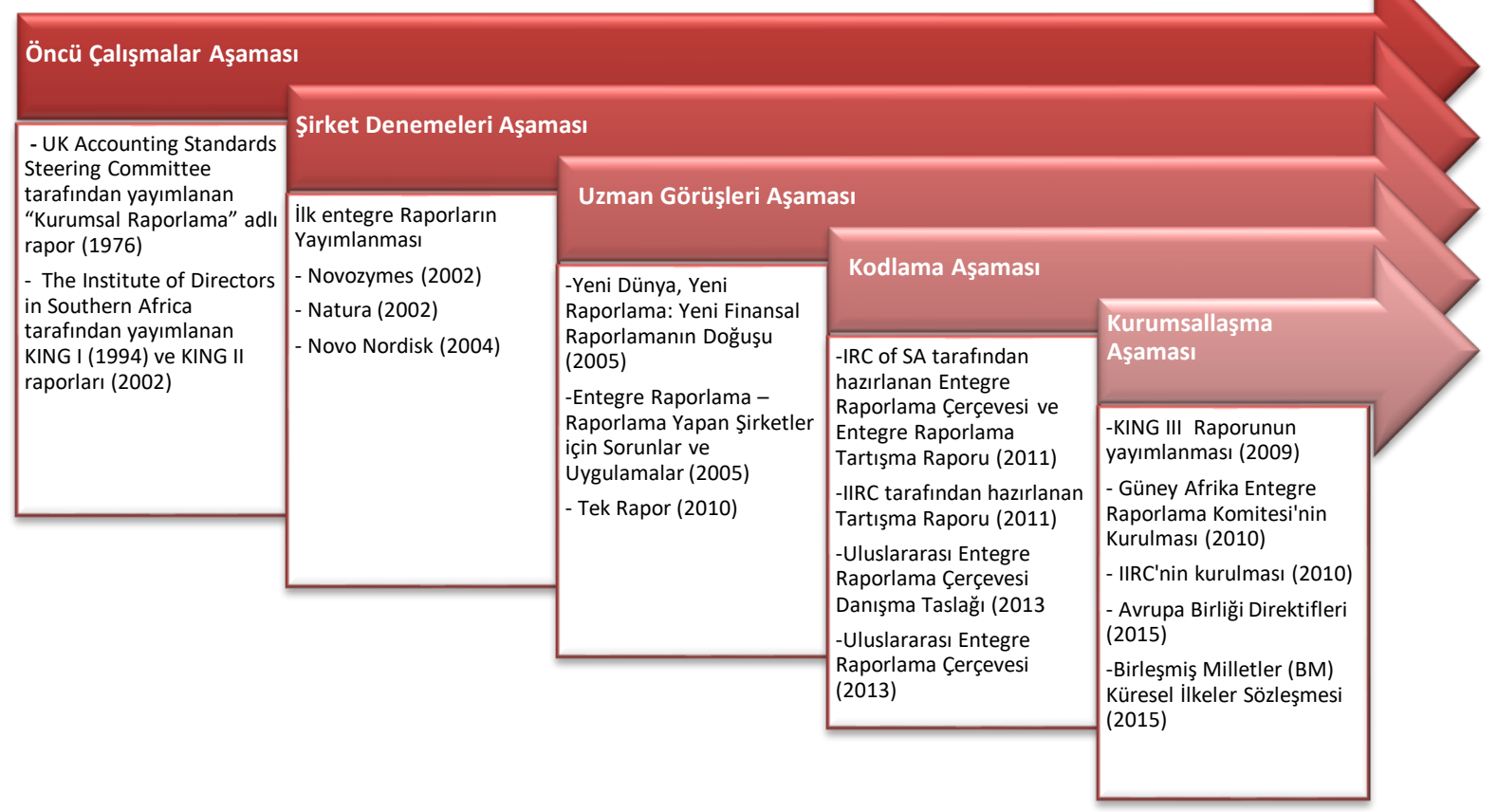

Şekil 2: Entegre Raporlama Aşamaları (Eccles, Krzus, \& Ribot, 2015)

2002 yılında ilk entegre raporlar Danimarkalı Novozymes ve Novo Nordisk ve Brezilyalı Natura şirketi tarafından yayımlamıştır. Bir biyoteknoloji şirketi olan Novozymes, "Entegre Y1llık Rapor, Çevresel ve Sosyal Rapor" (Integrated annual report, Environmental and Social Report) adıyla ilk entegre raporu paylaşmıştır (Eccles, Krzus ve Ribot, 2015). Şirket denemeleri aşaması olarak ifade edilen bu dönemde, temel amaç çevresel ve sosyal performansın çıkar gruplarına aktarılarak, sürdürülebilirliğe katkı sağladığı ifade edilebilir.

Gelişim sürecinin üçüncü aşamasına bakıldığında, Eccles ve Krzus (2015) üç farklı çalışmanın entegre raporlamanın gelişmesine katkı sağladığını ifade etmiştir. İlk çalışma, Allen White tarafından hazırlanmıştır. Rapor, kâr amacı gütmeyen "Business for Social Responsibility" (BSR) tarafından "Yeni Dünya, Yeni Raporlama: Yeni Finansal Raporlamanın Doğuşu (New Wine, New Bottles: The Rise of Non-Financial Reporting) (White, 2005) adıyla yayımlanmıştır. Raporda, Amerika'da Enron, WorldCom ve Tyco gibi, Avrupa'da ise Ahold, Parmalat and ABB gibi şirketlerin batmasından sonra yeni bir raporlamaya duyulan ihtiyaç dile getirilmiştir. İlk entegre raporlama yayımlayan şirketlerin finansal olmayan raporlamasının, dünyada standart bir rapor 
uygulama seviyesine yükselmesine öncülük ettiği söylenebilir. Ayrıca Allen White, finansal olmayan raporlamanın, anahtar göstergelerdeki, ölçüm tekniklerindeki, raporlama çerçevesindeki veya iletişim stratejilerindeki bazı problemleri nedeniyle başarısız olduğunu, finansal olmayan raporlama yerine, mali raporlamanın tek başına sunamadığı bilgileri çıkar gruplarına sunan entegre raporlamanın gelecekte kurumsal raporlamanın bir unsuru olabileceğini belirtmiştir. İkinci çalışma (Solstice, 2005), kâr amacı gütmeyen bir kuruluş olan "Solstice Sustainability Works" tarafından "Entegre Raporlama - Raporlama Yapan Şirketler için Sorunlar ve Uygulamalar" (Integrated Reporting- Issues and Implications For Reporters) adıyla yayımlanmıştır. Çalışmada, entegre raporlama tanımlanmış, entegre raporlamanın beklenen faydaları ve ortaya çıkabilecek sorunlar açıklanmıştır.

Uzman görüşleri aşamasının son çalışmasına bakıldığında, Eccles ve Krzus (2010) tarafından yayımlanan "Tek Rapor" (One Report) adlı çalışmada entegre raporlama kapsamlı bir şekilde anlatılmıştır. Bu çalışmanın hazırlanmasından sonraki dönemlerde birçok araştırmada ana kaynak olarak kullanılmış ve entegre raporlamaya öncülük eden en temel eserlerden biri olmuştur.

Kodlama aşaması dönemine bakıldığında, Eccles ve Krzus (2015) üç farklı çalışmayı öne çıkartmıştır. İlk entegre raporlama çerçevesi çalışması, Güney Afrika Entegre Raporlama Komitesi (The Integrated Reporting Committee of South Africa- IRC of SA) tarafindan "Entegre Raporlama Çerçevesi ve Entegre Raporlama Tartışma Raporu” (Framework for Integrated Reporting and the Integrated Report Discussion Paper) (IRCofSA, 2011) başlığıyla Mervyn King öncülüğünde yapılmıştır. IRC of SA tarafından hazırlanan rapor yayımlandıktan sekiz ay sonra, Mervyn King'in de üye olduğu ve çalışmalara katıldığ1 IIRC tarafından hazırlanan "Tartışma Raporu" (Discussion Paper) (IIRC, 2011) kamuoyu ile paylaşılmıştır. Hazırlanan rapor daha önce yayımlanan tartışma raporundan daha kapsamlı bir şekilde hazırlanmış, entegre raporlamanın ne olduğu, neden önemli olduğu ve diğer raporlama türlerinden nasıl farklı olduğu açıklanmıştır. Yapılan çalışmada, iş modeli ve değer yaratma gibi önemli kavramlara vurgu yapılmıştır. Ayrıca, dünyada her alanda önemli değişikliklerin olduğu bir dönemde raporlamanın da dönüşüm içinde olması gerektiği vurgulanmıştır.

Entegre raporlamanın standartlaştırma ve genel çerçeve oluşturma çalışmaları 2013 yılında IIRC tarafindan hazırlanan "Uluslararası Entegre Raporlama Çerçevesi Danışma Taslağı" (Consultation Draft of the International <IR> Framework) (IIRC, 2013c) dünya kamuoyu ile paylaşılmış ve farklı çevrelerden görüssler alınarak Uluslararası Entegre Raporlama Çerçevesi (The International <IR > Framework) (IIRC, 2013b) oluşturulmuştur. Oluşturulan çerçevede, ilk bölümde entegre raporlama kavramı tanımlanmış, temel kavramlardan değer yaratma, sermaye öğeleri kavramları ve değer yaratma süreci (iş modeli) açıklanmıştır. İkinci bölümde ise, entegre raporlama hazırlanma aşamasında kullanılacak kılavuz ilkeler ve içerik öğeleri tanıtılmıştır. Hazırlanan bu rapor birçok dilde yayımlanarak, entegre raporlamanın gelişimi sağlanmıştır.

Son aşamaya bakıldığında ise, ilk olarak 2009 yılında Mervyn King öncülüğünde KING III (KING III, 2009) raporu olarak bilinen rapor yayımlanmıştır. JSE tarafından yayımlanan bu rapor ile borsaya kote olan tüm şirketlerin entegre raporlama yayımlamasını, aksi durumda neden yayımlanmadığının açıklanması zorunlu hale getirilmiştir (Yücel, 2018). Aynı yıl içerisinde, Güney Afrika'da entegre raporlama ve entegre düşünce fikrinin yaygınlaşması için ilk konsey Güney Afrika Entegre Raporlama Konseyi (Integrated Reporting Council of South Africa) kurulmuştur. Uluslararas1 Muhasebeciler Federasyonu (International Federation of Accountants - IFAC) ve GRI iş birliği ile Uluslararası Entegre Raporlama Konseyi (The International Integrated Reporting Council - IIRC) İngiltere'de kurulmuştur. Kurumsallaşma açısından bu iki kuruluş, IRC of SA ve IIRC entegre raporlamanın kurumsallaşmasına ve yaygınlaşmasına önemli katkı sağlamıştır. Avrupa'da kurumsallaşma çalışmalarına ek olarak, 2015 yılında Avrupa Parlamentosuna üye 28 ülkeden 55'e karşı 599 oy ile finansal olmayan raporların yayımlanması ile ilgili bazı direktifler oy 
çokluğu ile kabul edilmesiyle gerçekleşmiştir. Bu direktiflere göre, şirketlerin çevresel, sosyal ve çalışanlar ile ilgili faaliyetleri ve aynı zamanda insan haklarına saygı, yolsuzlukla mücadele ve rüşvet gibi konulardaki politikaları, riskleri ve sonuçları ayrı veya bütünleşik olarak sunması gerektiği ifade edilmiştir. Yayımlanan bu direktif, Avrupa'da faaliyet gösteren yaklaşık 6.000 şirketi etkileyecektir (Eccles, Krzus, \& Ribot, 2015). Ayrıca, Birleşmiş Milletler (BM) Küresel İlkeler Sözleşmesi (The United Nations Global Compact), insan hakları, çevre ve yolsuzlukla mücadele gibi konularda evrensel olarak kabul edilmiş on ilke yayımlanmıştır. Dört başlık altında (İnsan Hakları, İşçi Hakları, Çevre ve Yolsuzlukla Mücadele) belirlenen bu on temel ilkenin yer aldığı sözleşmenin temel amacı, işletmeler ve tüm paydaşlar için sürdürülebilir kalkınmanın sağlanmasıdır (UN Global Compact, 2015). Bu ilkeler, entegre raporlamanın kurumsallaşma aşamalarından önemli bir adımı olarak nitelendirilebilir.

Entegre raporlamanın gelişiminde dünyada bu gelişmeler olurken, Türkiye'de ilk entegre rapor faaliyetleri, 2011 y1lında Türkiye Kurumsal Yönetim Derneği (TKYD) ve Sürdürülebilir Kalkınma Derneği'nin (SKD) oluşturduğu ortak bir çalışma grubu ile hayata geçirilmiştir. TKYD ve SKD, dünyada popüler olmaya başlayan ve aynı zamanda birçok uluslararası şirket tarafından yayımlanan entegre raporlamanın Türkiye'de farkındalık düzeyinin artırılması için çalışmaya başlamıştır. Ortak çalışma grubu IIRC ile iş birliği içinde hareket etmiş, 2013 yılında Garanti Bankası ve ÇİMSA, IIRC tarafindan hazırlanan pilot programına dahil edilmiştir (Yücel, 2018). 2015 yılında, Türkiye'nin ev sahipliği yaptığı G20 zirvesinde, B20 Bilgi Ortağı olarak seçilen ARGE Danışmanlık ve C20 Yönetişim Çalışma Grubu üyeliği yapan Argüden Yönetişim Akademisi’nin katkılarıyla, G20 zirvesine katılan liderlere yapılan önerilere entegre raporlama da eklenmiştir. Entegre raporlamanın Türkiye'deki en önemli çalışmaları arasında yer alan, TÜSİAD (Türk Sanayicileri ve İş İnsanları Derneği) tarafından desteklenen "Kurumsal Raporlamada Yeni Dönem: Entegre Raporlama" (Aras \& Sarığlu, 2015) adlı ilk çalışma yayımlanmıştır (ERTA, 2019). Yapılan çalışmada, kurumsal raporlamanın gelişimi hakkında bilgiler paylaşıldıktan sonra, entegre raporlamanın ne olduğu ve Uluslararası Entegre Raporlama Çerçevesi detaylı bir şekilde açıklanmıştır. Ayrıca, dünyada entegre raporlama örneklerine yer verilmiştir. İlk rehberin tanıtıldığı konferansta, entegre raporlama Türkiye bağlantısı için çalışmalara karar verilmiş, TÜSİAD, TKYD, Borsa İstanbul, IIRC Türkiye Büyükelçisi, Argüden Yönetişim Akademisi, Global Compact Network Türkiye, Garanti Bankası, SKD Türkiye ve Çimsa gibi şirket ve kuruluşların destekleriyle Entegre Raporlama Türkiye Ağı (ERTA) kurulmuştur. ERTA, Türkiye'de entegre raporlama çalışmalarına destek vererek farkındalığı artırmak ve tüm kurum ve kuruluşlarda entegre raporlamayı yaygınlaştırmak amacıyla kurulmuştur (ERTA, 2019).

Türkiye'de ilk entegre rapor bir sivil toplum kuruluşu olan Argüden Yönetişim Akademisi tarafından 2015 yılında yayımlanmıştır. Kâr amacı güden kuruluşlar içinde ilk rapor TSKB tarafından yayımlanmış, daha sonra ÇiMSA, OYAK Çimento Grubundan Aslan Çimento ve Adana Çimento olarak devam etmiştir. Tablo 1'de Türkiye'de entegre rapor yayımlayan kurum ve kuruluşlara yer verilmiştir.

Türkiye'deki entegre raporların çoğu özel şirketler tarafından yayımlanmış, 2020 yılında ilk defa bir kamu bankası entegre faaliyet raporu hazırlamıştır. Ayrıca, farklı sektör ve kuruluşlar entegre rapor yayımlamaya başlamış, Türkiye'de başlangıç seviyesinde olan entegre raporlamanın sınırlı olmakla beraber bu konudaki farkındalığının arttığı görülmüştür. Dünyada birçok uluslararası şirketin yayımladığı, bazı ülkelerde yasal düzenlemelerle zorunlu kılınan entegre raporlamanın Türkiye'de gerekli önemin verilmesi için ERTA gibi kuruluşların yapmış olduğu faaliyetler ve akademik çalışmalar önem arz etmektedir. 
Tablo 1: Türkiye'de Yayımlanan Entegre Raporlar (ERTA,2019)

\begin{tabular}{|c|c|c|c|c|c|c|}
\hline & \multirow[t]{2}{*}{ Kurum veya Kuruluşun Adı } & \multicolumn{5}{|c|}{ Entegre Rapor } \\
\hline & & 2015 & 2016 & 2017 & 2018 & 2019 \\
\hline Denetleyici Kuruluşlar & Borsa İstanbul (BİST) & & & $\checkmark$ & $\checkmark$ & $\checkmark$ \\
\hline Kamu Kurumları & $\begin{array}{l}\text { YTÜ Finans Kurumsal Yönetim ve } \\
\text { Sürdürülebilirlik Merkezi }\end{array}$ & & & $\checkmark$ & & \\
\hline \multirow{8}{*}{ Özel Sektör- Şirketler } & Garanti BBVA & & & $\checkmark$ & $\checkmark$ & $\checkmark$ \\
\hline & Türkiye İş Bankası & & & & & $\checkmark$ \\
\hline & Türkiye Sınai Kalkınma Bankası (TSKB) & & $\checkmark$ & $\checkmark$ & $\checkmark$ & $\checkmark$ \\
\hline & Adana Çimento & & $\checkmark$ & & & \\
\hline & Aslan Çimento & & $\checkmark$ & & & \\
\hline & Çimsa & & $\checkmark$ & $\checkmark$ & $\checkmark$ & \\
\hline & Nuh Çimento & & & $\checkmark$ & $\checkmark$ & $\checkmark$ \\
\hline & Vakıfbank & & & & & $\checkmark$ \\
\hline \multirow[b]{2}{*}{$\begin{array}{l}\text { Sivil Toplum } \\
\text { Kuruluşları }\end{array}$} & Argüden Yönetim Akademisi & $\checkmark$ & $\checkmark$ & $\checkmark$ & $\checkmark$ & $\checkmark$ \\
\hline & Türkiye Eğitim Gönüllüleri Vakfi (TEGV) & & & & & $\checkmark$ \\
\hline Yerel Yönetimler & Kadıköy Belediyesi & & & & & $\checkmark$ \\
\hline
\end{tabular}

\section{Entegre Rapor ile İlgili Literatür Taraması}

Çalışmanın bu kısmında, entegre raporlama üzerine yapılan çalışmalar incelenecektir. Literatür incelendiğinde, entegre raporlama yeni bir raporlama türü olduğu için, çalışmalar genellikle kavramsal incelemeler olmakla birlikte, son dönemlerde özellikle yayınlanan entegre raporlamaların içeriğinin incelendiği çok sayıda nitel çalışma ve az sayıda da nicel çalışmaların yapıldığı görülmektedir. Bu bağlamda, yapılan çalışmalar kavramsal incelemeler, nicel çalışmalar ve nitel çalışmalar olmak üzere üç farklı grupta verilmeye çalışılacaktır.

\section{Kavramsal Çalışmalar}

Kavramsal çalışmalar incelendiğinde, Uluslararası Entegre Raporlama Komitesi'nin kurulmasından önce Eccles ve Krzus (2010) tarafından yayınlanan "Tek Rapor: Sürdürülebilir Stratejiler için Entegre Raporlama“ (One Report: Integrated Reporting for a Sustainable Strategy) adlı çalışma entegre raporlamanın gelişimi için oldukça önem taşımaktadır. Çalışmada, tek raporun (entegre raporlama) ve entegre raporlamaya geçişte en önemli konuların ne olduğunu açıklamış, ilk entegre raporlama hazırlayan firma olan United Technologies Corporation (UTC) hakkında bilgiler verilmiştir. Çalışmada ayrıca, finansal ve finansal olmayan raporlamanın genel durumu hakkında bilgiler verildikten sonra, "It's Time for One Report" başlığı altında, tek bir rapora duyulan ihtiyaç ortaya konmuştur. Çalışmanın son kısmında ise, entegre raporlamanın teknoloji ile ilişkisi açıklandıktan sonra, sürdürülebilir bir toplum için entegre raporlamanın gerekliliği açıklanmıştır.

Entegre raporlamanın tanımlanmasına yönelik benzer çalışmalardan biri Eccles ve Armbrester (2011) tarafından yayınlanmıştır. Çalışmada, entegre raporlamanın tanımı yapılmış, sağladığı 
faydalar açıklanmıştır. Ayrıca, işletmelerin entegre raporlama yayımlamaya karar verdikten sonra, birçok teknoloji ve data sorunu ile karşı karşıya kalacağını belirtmiştir. Bu sorunlara karşı, bulut (cloud) teknolojisinin nasıl yardımcı olacağı hakkında bilgilere yer verilmiştir. Yine Karğın ve diğerleri (2013) tarafindan yapılan çalışma Türkiye'de entegre raporlama üzerine yapılan ilk çalışmalardan biri olarak önem arz etmektedir. Çalışmada, entegre raporlama hakkında bilgiler sunulduktan sonra, raporlamanın içeriği ve dünyadaki örnekleri hakkında bilgiler verilmiştir. Ayrıca, bir entegre raporlama önerisi de yapılmıştır.

Eccles ve Serafeim (2011), entegre raporlama konsepti, kısa bir gelişim tarihini anlatmış, ayrıca entegre raporlama uygulamalarının değerlendirmesini yapmıştır. Çalışmada, ülkelerin çevresel, sosyal ve yönetimsel bilgiye olan ilgisi "düşük ve yüksek" olarak belirlenmiş, hangi ülkedeki şirketlerin ve yatırımcıların finansal olmayan bilgiye ilgi duyduğu belirtilmiştir. Çalışmanın sonucunda ise, entegre raporlamanın oldukça önemli olduğu belirtilmiş; firmaların, yöneticilerin, yatırımcıların ve devletin entegre raporlamanın gelişimine olan desteğinin artması gerektiği ifade edilmiştir.

Simnett ve Huggins (2015), IIRF'nin geliştirilmesinde göze çarpan konulara ve ortaya çıkan sorunlara yönelik bilgi vermiştir. IIRC tarafindan, birden fazla sermaye kavramını kullanarak bir şirketin iş modelinin tanımını gerektiren, özlü, kullanıcı odaklı bir kurumsal raporun hazırlanması için bir raporlama çerçevesi hazırlamıştır. Hazırlanan bu raporlamanın uluslararası kabul görebilirliğini artırabilmek için piyasada faaliyet gösteren şirketlere entegre raporlamanın faydalarının araştırmacılar tarafından sağlanması gerektiği çalışmada ifade edilmiştir. Ayrıca, IIRF’nin hazırlanması esnasında ortaya çıkan sorunlar belirlenmiş, gelecekteki çalışmalar için bir dizi araştırma önerisi sunulmuş ve akademisyenlerin Entegre Raporlama Çerçevesine göre raporlayan şirketlerin maliyetlerini ve faydalarını değerlendirebilecekleri ve bu bilgiyi temin edecekleri araştırma yaklaşımları özetlenmiştir. Bernardi (2015) ise, entegre raporlama ile ilgili çalışmaların nasıl devam ettiğini, literatürde yapılan eleştirileri ve literatürün odaklandığı konuları ortaya koymaya çalışmıştır.

Flower (2015), 2010 y1lında kurulan, temel hedefinin sürdürülebilirlik muhasebesinin teşvik etmesi gereken IIRC'nin tarihsel gelişimini izlemiştir. IIRC'nin sürdürülebilirlik konusundaki mevcut yaklaşımını, Aralık 2013'te yayımlanan çerçeveye dayanarak analiz etmiştir. Yapılan analiz sonucunda IIRC'nin değer kavramının "yatırımcılar için değer" olduğu ve "toplum için değer" olmadığı ve IIRC'nin, firmalara, şirket dışındaki kuruluşlara (çevre gibi) zararları bildirme yükümlülüğü getirmediğini ifade etmiştir. Raporun, IIRC'nin kurumsal raporlama uygulamas1 üzerinde güçsüzlükleri nedeniyle çok az etkisinin olacağını savunmuştur. Ayrıca, IIRC'nin sürdürülebilirlik muhasebesini terk etmesinin sebebi olarak çokuluslu işletmelerin hakim olduğu IIRC'nin yönetim konseyinin olduğu ifade edilmiştir. Aslında entegre raporlamanın sürdürülebilirliğe katk1 sağlaması gerekirken, sürdürülebilirlik raporlamasının içinde yer alan bilgileri sunmadığı belirtilmiştir. Adams (2015) ise, entegre raporlama ve sürdürülebilirlik raporlamasının önemli farklı1ıklarını tartışmıştır. Çalışma, Flower (2015) çalışmasına eleştiri olarak hazırlanmıştır. Flower, çalışmasında entegre raporlamanın şirketler üzerinde çok az etkisinin olacağını ifade ederken, Adams (2015) karşıt olarak güçlü bir etkisinin olduğunu, birçok şirketin belirli ücretler ödeyerek pilot programlara dahil olduğunu ve diğer şirketlerin de gönüllü olduğunu ifade etmiştir. Çalışmanın sonunda, entegre raporlamanın gelişeceğini, şirketler ve yatırımcılar üzerinde etkili olacağını belirtilmiştir.

Aras ve Sarığlu (2015) tarafından "Kurumsal Raporlamada Yeni Dönem: Entegre Raporlama" adlı çalışma hazırlanmıştır. Bu rapor, entegre raporlamanın Türkiye'de gelişmesi açısından oldukça önemlidir. Yapılan çalışmada, entegre raporlamanın kavramsal çerçevesi hakkında geniş bilgiler sunulmuş, Uluslararası Entegre Raporlama Çerçevesinin ilkeleri, içerik 
öğeleri, sermaye öğeleri tanıtılmış ve iş dünyası ve yatırımcıların gözünden entegre raporlama değerlendirilmiştir.

Hoque (2017), şirketlerin neden entegre raporlamaya adapte olması gerektiği üzerine bir araştırma yapmıştır. Entegre raporlamanın finansal ve finansal olmayan bilgiyi bir araya getirerek paydaşların ihtiyaç duyduğu bilgileri tek bir raporda sağlayacağını belirtmiştir. Çalışmada, kısaca bir entegre raporlamanın ne olduğu ve kısa bir tarihi sunulmuş, çalışmanın sonunda da neden entegre raporlamaya geçilmesinin gerekli olduğu açıklanmıştır. Çalışmanın sonucunda, entegre raporlamanın karmaşık bir yapıya sahip olmasına rağmen, paydaşların ihtiyaç duyduğu tüm bilgileri sağladığı için, şirketlerin entegre raporlamaya geçiş yapmasını önermiştir.

Çelebier ve Çankaya (2019), 2011-2018 tarihleri arasında entegre raporlama üzerine yapılan 200 çalışmayı incelemiş, entegre raporlama konusu ile doğrudan ilişkili olan 43 çalışmayı inceleyerek, kısaca çalışma sonuçlarını açıklamıştır.

\section{Nicel Çalışmalar}

İkinci grupta, entegre raporlama üzerine yapılan nicel çalışmalar incelenmiştir. Aceituno ve diğerleri (2013), hukuk sisteminin entegre raporlamayı geliştirmesi üzerindeki etkisini incelemeye çalışmıştır. 2008-2010 yılları arasında 750 şirketin üzerine yapılan araştırmada, gelişmiş hukuk sistemine sahip ülkelerde entegre raporlama yayımlama olasılıklarının daha yüksek olduğunu ampirik olarak kanıtlamıştır. Şeffaflığın ve hesap verebilirliğin artırılması için ulusal yasalara ve onları koruyan mekanizmalara ihtiyaç olduğunu belirtmiştir.

Churet ve Eccles (2014), entegre raporlamanın finansal performans ve yönetim kalitesi olan ilişkisini araştırmak için bir araştırma yapmıştır. Çalışmada, entegre raporlama ve finansal performans arasında anlamlı bir ilişki olmadığı ampirik olarak kanıtlanmış, ancak entegre raporlama, uzun vadeli rekabet edebilirliği korurken işletmelerin kısa vadeli hedeflere ulaşmalarına yardımcı olan ESG yönetiminin kalitesini artırabileceği ifade edilmiştir.

Serafeim (2014), entegre raporlama uygulayan firmalar ile Amerika' daki yatırımcı tabanının yapısı arasındaki ilişkiyi incelemiştir. Çalışmada, entegre raporlama uygulayan firmaların uzun vadeli yatırımcı tabanına sahip olduğu ampirik olarak kanıtlanmıştır. Ighian (2015) ise, yatırımcılar tarafından talep edilen finansal ve finansal olmayan bilgiler ile iç ve dış çevre için hazırlanan entegre raporlamanın etkinliği, şeffaflığı ve tutarlılığı geliştireceğini, aynı zamanda da pazarda güven sağlayacağını ve yatırımcı tabanında bir artışın olacağını gözlemlemiştir.

Küçükgergerli (2017), uluslararası düzeyde kullanılacak bir entegre raporlama endeksi oluşturmaya ve aynı zamanda firmaların borsa değeri ile entegre performansı arasındaki ilişkisini açıklamaya çalışmıştır. Çalışmada, 2010-2014 yılları arasında 5 yıllık bir dönem için entegre raporlama endeks notları oluşturulmuş ve bu notlar firmaların hisse senedi değeri ile panel veri analizine tabi tutulmuş ve anlamlı sonuçlar elde edilmiştir.

Solak ve diğerleri (2017), Aydın ve Malatya illerinde bulunan muhasebe meslek mensuplarının entegre raporlama farkındalık düzeylerinin belirlenmesine yönelik bir anket çalışması uygulamış, meslek mensuplarının entegre raporlama konusunda yeterli farkındalığa ve bilgiye sahip olmadıklarını ampirik olarak kanıtlamıştır. Benzer olarak Topal (2019) Bursa'da, Besler (2019) ise İstanbul'da muhasebe meslek üyelerinin entegre raporlama farkındalık düzeylerini ölçmüş, katılımcıların entegre raporlama hakkında yeterli algı ve farkındalığa sahip olmadığını ortaya çıkarmıştır. Karaburun (2019), İzmir ilinde faaliyet gösteren muhasebe meslek gruplarının muhasebe kültürüne nasıl baktıklarını, aynı zamanda meslek mensuplarının entegre raporlamaya karşı farkındalığını belirlemeye çalışmıştır. Araştırmada, muhasebe meslek gruplarının entegre raporlama hakkında farkındalığa sahip olduğu belirlenmiştir. Ayrıca, entegre raporun denetlenmesi gerektiği ifade edilmiştir. 
Çelebier (2018), BİST sürdürülebilirlik endeksinde yer alan firmaların, entegre raporlamada yer vermesi gereken içerik öğelerini ve entegre raporun nasıl olacağını belirlemeyi amaçlamıştır. Çalışmanın bulguları incelendiğinde, firmaların çevresel performanslarının düşük seviyede olduğu tespit edilmiştir. Ayrıca, Kurumsal Yönetim Endeksi'nde yer alma, holding üyeliği ve BİST'te işlem görme yaşı değişkenlerinin çevresel ve sosyal performans göstergelerinin herhangi bir boyutunda farklılığa neden olmadığ 1 ortaya çıkarılmıştır. Çalışmasının diğer bulgularından biri, firma yöneticilerinin, entegre raporlama hakkında yeterli farkındalığa sahip olmadığıdır.

Çelik (2019), 2016 ve 2017 yıllarında BİST Sürdürülebilirlik Endeksi'ne tabi şirketlerin faaliyet, entegre ve sürdürülebilirlik raporlarını inceleyerek, IIRC tarafindan hazırlanan Uluslararas1 Entegre Raporlama Çerçevesinde (IIRF) yer alan kılavuz ilkelere uygun olup olmadığının içerik analizi ile ortaya koymaya çalışmıştır. Çalışmada, BIIST'te yer alan 44 şirketin aktif karlılığ 1 (ROA) ve özkaynak karlılığı (ROE) değerlendirilmiş, entegre raporlama yayımlamayan şirketlerin performans göstergeleri; aktif karlılığ $1 \% 55$, özkaynak karlılı̆̆ını ise \%32 oranda etkilerken, rapor yayınlayan üç şirketin (TSKB, Garanti ve Çimsa) performans göstergelerinde, aktif karlılığı \%70, özkaynak karlılı̆̆ını ise \%82 oranında etkilediği ortaya çıkarılmıştır. Bu bağlamda, Churet ve diğerlerinin (2014) ve Chiu (2016) tarafından yapılan çalışmalarının aksine, entegre raporlamanın finansal performans üzerinde olumlu bir etkiye sahip olduğu ifade edilmiştir.

\section{Nitel Çalışmalar}

Son olarak nitel çalışmalar incelendiğinde, yapılan çalışmaların önemli bir kısmını içerik analizinin oluşturduğu görülmektedir. Entegre raporlama tartı̧̧ma raporu yayınlandıktan sonra, ilk içerik çalışmalarından biri Solomon ve Maroun (2012) tarafından yayımlanmıştır. Çalışmada, JSE'de faaliyet gösteren 10 farklı Güney Afrika şirketinin raporları sosyal, çevresel ve etik raporlama üzerindeki etkisi incelenmiştir. Çalışmanın bulgularına bakıldığında, hem olumlu hem de olumsuz etkilerinin gösteren karmaşık bir resmin olduğu ifade edilmiş̧ir. Aynı sektörde faaliyet gösteren şirketlerin, çevresel, sosyal ve etik konuları ile ilgili farklı sunum yaptıkları ortaya çıarılmıştır.

Ercan ve Kestane (2014), entegre raporlama ve Türkiye'deki uygulama örnekleri üzerine bir araştırma yapmıştır. Çalışmada, Türkiye Sınai Kalkınma Bankası tarafindan hazırlanan entegre raporlama, içerik analizine tabi tutulmuş ve hazırlanan raporun uluslararası entegre raporlama konseyi tarafından hazırlanan entegre raporlama çerçevesine uygun olarak hazırlandığı tespit edilmiştir.

Aydın (2015), 2012-2013 yıllarında Borsa İstanbul'da faaliyet gösteren işletmelerin entegre raporlama ile uyum düzeylerini araştırmış, şirketlerin faaliyet raporlarını inceleyerek entegre raporlamaya hazırlık potansiyelini tespit etmiştir. Kurumsal sosyal sorumluluk ölçeği, entegre raporlamanın içerik öğelerine uygulanarak bir içerik çözümlemesi formu oluşturmuş, BİST’te yer alan firmaları "iyimser", "kötümser", ve "nötr", olarak değerlendirmiş ve buna göre sıralamasını yapmıştır.

Petersen ve Svensson (2016), kurumsal raporlama hazırlama esnasında uluslararası entegre raporlama çerçevesine uyma zorunluluğunun raporlardaki entelektüel sermaye açılamalarını nasıl etkilediğini araştırmıştır. Güney Afrika Borsasında listelenen firmalardan seçilen entegre raporlamaların içeriğini incelemiş, entelektüel sermaye bilgisine sahip olup olmadığ 1 konusunda bir puan tablosu oluşturmuştur. Çalışmada, entegre raporlamanın zorunlu olmasından sonra, şirketlerin entelektüel sermaye sunum miktarında artış olduğu tespit edilmiştir. Ayrıca, çalışmada, Güney Afrika ve İsviçre ülkelerinin entegre raporlama sunumları bazı kategorilerde karşılaştırılmıştır.

Yılmaz (2016), entegre raporun önemli bileşenlerinden olan değer yaratma ve diğer rapor içeriği ve sermaye öğelerini yatırımcılar açısından analiz etmiştir. Türkiye'de o tarihte herhangi bir entegre raporlama olmadığı için yurtdışında yayınlanan dört firmanın (Southwest Hava Yolları, Kumba Iron, Novozymes, SAP) entegre rapor içeriğini incelemiştir. Çalışmada, incelenen her bir 
firmanın sermaye öğeleri ve iş modeli farklılık göstermiş̧tir. Ayrıca, başarılı entegre raporlama sunumuna sahip olan SAP şirketinin entegre raporundan yararlanılarak entegre yatırım analizi modeli ve algoritması oluşturulmuştur. SAP 2015 entegre raporunda içerik öğelerinin yatırım analizi algoritma uygulaması sonucunda; SAP firmasının başarılı bir şekilde bilgileri entegre ettiği, finansal ve finansal olmayan verilerin ilişkisinin açıklandığı, anahtar performans göstergelerinin ele alındığ ve gelecek hakkındaki bilgilere yer verildiği görülmüştür. Fakat rakip firmalarla ilgili herhangi bir karşılaştırmaya gitmediği de tespit edilmiştir.

Kaya ve diğerleri (2016), 13 farklı ülkede faaliyetlerini devam ettiren işletmelerin entegre raporlama içeriğini ve kapsamını incelemiş, raporların ortak ve farklı özelliklerini tespit etmeye çalışmıştır. Bulgular incelendiğinde, raporların çoğunun benzer ifadelerin kullanılmasıyla "kısa ve özet” olma ilkesi ile çeliştiği, hedef kitlesi olarak sadece yatırımcıların değil, tüm paydaşların dikkate alındığı ortaya çıkarılmıştır. Benzer olarak Yüksel (2017), Elmacı ve Sevim (2017) entegre raporlama örneklerini inceleyerek içerik analizi yapmış ve ilerde entegre raporlama uygulayacak firmalar için çeşitli öneriler sunmuştur.

Yüksel ve ARACI (2017), BİST Kurumsal Yönetim Endeksi'nde yer alan firmaların entegre raporlamaya uygun olup olmadığını, faaliyet raporları inceleyerek tespit etmeye çalışmış, entegre raporlamada yer alan içerik öğelerine göre belirlenen bir puan sistemi oluşturarak, firmaları puanlarına göre sıralamıştır. Ayrıca, çalışmanın sonuç kısmında, entegre raporlama hakkında çeşitli önerilere yer vermiştir.

Sevim (2018), entegre raporlama teorisi hakkında bilgilere yer verdikten sonra, 5018 sayıl1 Kanun kapsamında üniversitelerin yayınlamak zorunda olduğu çeşitli raporları ve bilgi setlerini incelemiş, entegre raporlamada yer alan içerik öğeleri açısından değerlendirmiştir. Elde edilen bu değerlendirme sonucunda, üniversitelerin entegre raporlamada yer alan kılavuz ilkeleri ve içerik öğeleri doğrultusunda entegre raporlama örneği sunulmuştur. Benzer olarak, Yıldırım ve Kocamış (2018), entegre raporlamanın genel çerçevesini ortaya koymaya çalışmış ve Türkiye'de ve dünyada yayınlanan bazı entegre raporları içerik analizine tabi tutmuştur. Yücel (2018) ise, Türkiye'de yayınlanan tüm entegre raporları içerik analizine tabi tutmuştur. Benzer bir çalışma olarak, Sarıŏlu (2018) entegre raporlama hakkındaki gelişmeleri ortaya koymuş, entegre raporlamanın iş dünyasına, yatırımcılara, pay sahiplerine ve tüm paydaşlara olan etkisini açıklamaya çalışmıştır. Bu çalışmada, Türkiye'de hazırlanan ilk entegre raporun içerik analizi yapılmıştır.

Berksoy (2018), entegre raporlama metodolojisinin sektörel bazda karşılaştırmalı değerlendirilmesini yapmıştır. Türkiye'de yayınlanan üç firmanın entegre raporlarını inceleyerek karşılaştırmıştır. Çalışmada, entegre raporlamanın maliyetlerde bir azalma meydana getirdiği, şirketin daha iyi risk analizi yapma kapasitesine sahip olduğu ortaya çıkarılmıştır. Aynı zamanda marka saygınlığını da sağladığı araştırma sonuçlarında belirtilmiştir. Fakat, içerik analizi incelendiğinde entegre raporlama uygulayan şirketlerin rekabeti dikkate alarak iş modelini tam olarak açıklamadığı, bazı bilgileri gizlilik sebebi ile sakladığı belirtilmiştir.

Şimşek (2018), Türkiye'de 2016 yılı itibari ile entegre raporlama yayımlayan beş şirketin raporlama içeriğini Uluslararası Entegre Raporlama Çerçevesinin içerik öğelerine uyumluluğunu incelemiş, firmaların sermaye ve içerik öğeleri açısından farklılık gösterdiğini ve içerik öğelerinin gerekliliklerini önemli ölçüde karşılasa da bazı noktalarda eksikliklerin var olduğunu ortaya çıkarmıştır.

Oral (2018), 2016 y1lı Fortune Global 500 listesinde yer alan 50 şirketin entegre rapor içerik öğelerini incelemiş, raporların Uluslararası Entegre Raporlama Çerçevesinde belirtilen içerik öğelerini ne ölçüde yansıttığını ortaya koymaya çalışmıştır. Bulgulara bakıldığında, şirketlerin içerik öğelerinden en çok kurumsal genel görünüm ve dış çevre içeriğini yayımladığını ve her bir firmanın kendine özgü bir işletme modeli sunduğunu tespit etmiştir. 
Berberoğlu (2019), Uluslararası Entegre Raporlama Çerçevesinin sermaye öğeleri ve kılavuz ilkeler bağlamında ne yönde bir değişimin olduğunu ortaya çıkarmıştır. Çalışmada, 2013-2018 yılları arasında Afrika Johannesburg Borsasında (JSE) faaliyetlerine devam eden altı farklı bankanın (Absa Group Limited, Nedbank Group Limited, Standard Bank Group, Firstrand Group, Finbond Group Limited, Capitec Bank Holdings Limited) entegre raporları içerik analizi ile incelenmiştir. Bu bağlamda, iki farklı skor oluşturulmuştur. İlk skor, çerçevede belirtilen sermaye öğeleri hakkında açıklama yapıp yapmadığına göre puan vererek oluşturulmuş; ikinci skor ise, paylaşılan bilgilerin kılavuz ilkelere uyumlu olup olmadığı dikkate alınarak belirlenmiştir. Skorlar incelendiğinde, Afrika'da faaliyet gösteren altı bankanın entegre rapor skorları her bir yıl itibari ile arttığı belirlenmiş, fakat gerek sermaye öğeleri hakkında yeterli bilgi paylaşımının olmaması, gerekse de kılavuz ilkelere uyumlu olunması hususunda yeterli gelişmenin olmadığı tespit edilmiştir.

Tepedelen (2019), Türkiye'de faaliyet gösteren iki farklı bankanın (TSKB ve Garanti Bankası) IIRC'nin belirlemiş olduğu kılavuz ilkelere uyup uymadığını içerik analizi ile ortaya koymaya çalışmıştır. Çalışmada, TSKB ve Garanti Bankası tarafından yayınlanan entegre raporlamanın IIRC'nin belirlemiş olduğu çerçeve ile yüzde yüz uyumlu olduğu belirlenmiştir.

İçerik analizi çalışmalarından farklı olarak yapılan bazı nitel çalışmalara aşağıda yer verilmiştir. Steyn (2014), Afrika'da borsada listelenen şirketlerin üst düzey yöneticilerinin, entegre raporlama uygulaması ile elde ettikleri fayda ve uygulama zorlukları üzerine bir araştırma yapmıştır. Çalışmada, Güney Afrika'da hızlıca yayılan entegre raporlama çerçevesinin kurumsal itibar, yatırımcı talepleri ve paydaş katılımı ve ilişkileri noktasında entegre raporlama sürecine önemli değer kattığ1 ve bu sürecin bir raporlama sistemi olarak gönüllü entegre raporlama çalışmalarına katkı sağlayacağı ifade edilmiştir. Ayrıca, entegre rapor içeriğindeki bilgilerin kurumsal itibar ve paydaş ihtiyaçlarının çıkar gruplarına iletilmesinden daha ziyade rapor içeriğinin meşrulaştırılması nedeniyle yöneticiler tarafindan benimsendiği belirtilmiştir.

Goldman (2014), Johannesburg Borsasında ilk yüz şirketin entegre raporlama sürecinde sürdürülebilirliğe ne ölçüde odaklandığını, ayrıca şirketlerin sürdürülebilirliği nasıl entegre ettiği ve başarılı bir entegre raporlama sürecinde sürdürülebilirlik çabalarının nasıl bir rol oynadığını araştırmıştır. Araştırmada, sürdürülebilirlik raporlamasının entegre raporlamayı destekleyebileceği arzulanırken, bu iki konseptin birbirinden bağımsız olduğu ve birbirini desteklemediği ortaya çıkarılmıştır.

Higgins ve diğerleri (2014), Avusturya'da öncü entegre raporlama uygulayan şirket yöneticilerinin entegre raporlamanın kurumsallaşmasına nasıl katkıda bulunduğunu araştırmıştır. Çalışmada, işletme yöneticilerinin entegre raporlamayı stratejik öykü ve paydaş beklentilerini anlatma aracı olarak gördüğü ifade edilmiştir.

Havlova (2015), 2010 - 2014 yılları arasındaki 48 özel ve kamu işletmesinin entegre raporlarını, sayfa sayılarını ve işletmelerin bilgi teknoloji kullanımını araştırmıştır. Bulgulara bakıldığında, entegre raporlama uygulayan özel şirketlerin daha fazla açıklama yayımlamasına rağmen entegre rapor sayfa sayısının azaldığı ve aynı zamanda bilgi teknolojisine odaklanıldığı ifade edilmiştir. Kamu kuruluşlarının ise, entegre rapor sayfa sayısının azaldığı, fakat rapor yayımlamada çok fazla gönüllü olmadığı sonucuna varılmıştır.

\section{Sonuç}

Çalışmada, öncelikle entegre raporlama kavramı tanımlanmış, Eccles ve Krzus tarafından belirlenen entegre raporlamanın tarihsel gelişim aşamalarına, öncü çalışmalar aşaması eklenmiş ve entegre raporlamanın tarihsel gelişimine yer verilmiştir. Ayrıca, Türkiye'deki gelişim süreci de anlatılmıştır.

Entegre raporlamanın aşamalarına bakıldığında, entegre raporlamanın oluşumunda katkı sağlayan öncü çalışmalar olarak KING I ve KING II raporları önem arz etmektedir. Daha sonra 
yayınlanan şirket entegre raporları, sürdürülebilirliği dikkate alarak şirketlerin entegre raporlama yapmasını teşvik etmiştir. Yayınlanan bu şirket raporları, uzmanlar tarafından değerlendirilmiş, entegre raporlamanın tanımı, amacı ve önemine yer verilmeye başlanmıştır. Kurumsallaşma aşamasında, uluslararası iş birlikleri ile entegre raporlama komitesi kurulmuş ve uzman kişiler tarafından tanımı ve amacı belirlenen entegre raporlamanın çerçevesi hazırlanmıştır. Çalışmada, bu aşamalara kısaca yer verilerek, entegre raporlamanın tarihsel gelişimine katkı sağlayan çalışmalar ve kurumlar açıklanmıştır. Dünyada bu gelişmeler yaşanırken, Türkiye'de TKYD'nin ve SKD'nin ortak çalışması ile başlayan süreç kısaca anlatılmıştır.

Entegre raporlama üzerine yapılan çalışmalara üç başlık altında yer verilmiştir. Kavramsal çalışmalar incelendiğinde, çalışmaların çoğu entegre raporlamanın ne olduğunu, tarihsel gelişimini, entegre raporlama üzerine yapılan çalışmaları, faydalarını ve ortaya çıkabilecek sorunları incelemeye çalışmıştır. 2010'lu yıllardan itibaren popüler olmaya başlayan entegre raporlamanın kavramsal olarak incelenmesi, entegre raporlamanın hala gelişme aşamasında, özellikle raporlama çerçevesinin ilkeleri, öğeleri gibi konularda geliştirilmesi gereken birçok konunun olduğu görülmektedir. Entegre raporlamanın kavramsal çerçevesinin gelişimi sonraki yıllarda devam edeceği öngörülmektedir. Özellikle, henüz entegre raporlama denetimi için gerekli olan standartların, kuralların ve uygulamaların olmayışından dolayı kavramsal çalışmaların artarak devam edeceği tahmin edilmektedir. Nicel çalışmalar incelendiğinde, kavramsal ve nitel çalışmalara göre sınırlı sayıda çalışmanın olduğu görülmüştür.

Yapılan nitel çalışmalar incelendiğinde, çalışmaların çoğunun içerik analizi çalışmaları olduğu görülmektedir. Yeni bir raporlama türü olan entegre raporlamanın, IIRC tarafindan yayınlanan çerçeveye uygunluğunun araştırıldığı içerik analizi çalışmaları, entegre raporlama üzerine yapılan çalışmalarda önemli bir yer teşkil etmektedir. Ayrıca, içerik analizleri dışında, az sayıda nitel çalışmanın olduğu da görülmüştür.

Entegre rapor üzerine birçok uluslararası çalışma olmasına rağmen, çalışmaların önemli bir kısmının kavramsal çalışmalar ve içerik analizleri olduğu tespit edilmiştir. Bu bağlamda, entegre raporlamanın hala gelişim aşamasında olduğu söylenebilir. Ek olarak, Türkiye'de yayımlanan entegre rapor sayısının az olması, yapılan araştırmaların önemli kısıtlarından biridir. Türkiye'de yapılan çalışmalar, literatüre katkı sağlamalarına rağmen, sonuç elde edebilmek için sınırlı kalmaktadır. Bu sebepten dolayı, ilerleyen dönemlerde yayınlanan entegre raporlama sayısındaki artış, çalışmalar için daha sağlıklı sonuçlar elde edilmesini kolaylaştıracaktır.

\section{Kaynakça}

Aceituno, J. F., Ariza, L. R., \& Sánchez, I. G. (2013). Is Integrated Reporting Determined by a Country's Legal System? An Exploratory Study. Journal of Cleaner Production, 45-55.

Aras, G., \& Sarığlu, G. U. (2015). Kurumsal Raporlamada Yeni Dönem: Entegre Raporlama. İstanbul: TÜSİAD.

Aydın, S. (2015). Entegre Raporlama. Türkmen Kitapevi.

Berberoğlu, V. (2019). Entegre Raporlama Uygulamalarının Çoklu Sermaye Öğeleri Ve Kılavuz İlkeler Çerçevesinde Analizi. İstanbul: Yıldız Teknik Üniversitesi Sosyal Bilimler Enstitüsü.

Berksoy, B. (2018). Sürdürülebilirlik ve Entegre Raporlama Metodolojisinin Sektörel Bazda Karşılaştırmalı Değerlendirilmesi, Işık Üniversitesi Sosyal Bilimler Enstitüsü.

Bernardi, C. (2015). Integrated Reporting- Insights Critical İssues and Future Research Agenda. 
Besler, Ö. N. (2019). Muhasebe Meslek Mensuplarının Entegre Raporlama Algılama Düzeyleri Üzerine Bir Araştırma. Tokat Gaziosmanpaşa Üniversitesi, Sosyal Bilimler Enstitüsü Yüksek Lisans Tezi.

Borsa İstanbul. (2014). Şirketler için Sürdürülebilirlik Rehberi. Borsa İstanbul.

Chiu, C. (2016). Integrated Reporting: Exploring the effects of Integrated Reporting in South Africa, Erasmus University Rotterdam, Master Thesis.

Churet, C., \& Eccles, R. G. (2014). Integrated Reporting, Quality of Management and Financial Performance. Journal of Applied Corporate Finance, 8-16.

Çelebier, M., \& Çankaya, F. (2019). Entegre Raporlama ile ilgili Yapılan Çalışmalar: Literatür Çalışması. Uluslararası Ekonomi ve Yenilik Dergisi, 179-196 .

Çelik, L. (2019). Entegre Raporlamanın İşletmelerin Finansal Performansları Üzerindeki Etkisinin Yapısal Eşitlik Modeli ile Ölçülmesi. Tekirdağ Namık Kemal Üniversitesi Sosyal Bilimler Enstitüsü.

Eccles, R. G., \& Saltzman, D. (2011). Achieving Sustainability Through Integrated Reporting, Stanford Social Innovation Review 9(3), 56-61.

Elmac1, O., \& Sevim, Ş. (2017). Entegre Raporlamada Küresel Gelişmeler ve Türkiye İçin Bir Model Önerisi. Uluslararası Sosyal ve Ĕ̈itim Bilimleri Dergisi, 18-36.

Ercan, C., \& Kestane, A. (2014). Kurumsal Raporlamada Yeni Bir Yaklaşım Olarak Entegre Raporlama ve Bir Vaka Çalışması. ASSAM Uluslararası Hakemli Dergi 4(8), 13-29.

ERTA. (2019). Entegre Raporlama Türkiye Hakkinda. Entegre Raporlama Türkiye: http://entegreraporlamatr.org/tr/hakkimizda/biz-kimiz.aspx

Goldman, J. (2014). INTEGRATED REPORTING: Inspiring companies to integrate sustainability into their business strategy and practice? .

Gökten, S. (2016, Aralık). Entegre Raporlama Yaklaşımı İçin Uygulamaya Yönelik Sistematik Bir Öneri . Muhasebe Bilim Dünyası Dergisi, 18(4),741 - 765.

GRI. (2019). About Sustainability Reporting : https://www.globalreporting.org/information/sustainability-reporting/Pages/default.aspx

Hertgers, I. (2016). Integrated reporting The implementation and development of integrated reporting at TenneT, Radboud University Nijmegen Schoolof Management Master Thesis Economics Accountancy \& Control.

Higgins, C., Stubbs, W., \& Love, T. (2014). Walking the Talk(s): Organisational Narratives of Integrated Reporting. Accounting \& Auditing Accountability Journal, 1090-1119.

Hoque, M. E. (2017). Why Company Should Adopt Integrated Reporting? International Journal of Economics and Financial, 241-248.

Ighian, D. S. (2015). Ontegrated Reporting - The Future of Financial Reporting. Internal Auditing and Risk Management, 125-134.

IIRC. (2011). Discussion Paper (Towards Integrated Reporting Communicating Value in the 21st Century). Integrated Reporing Council.

IIRC. (2013a). Uluslararası $<E R>$ Çerçevesi. International Integrated Reporting Council.

IIRC. (2013b). The International $\langle I R\rangle$ Framework. The International Integrated Reporting Council. 
IIRC. (2013c). Consultation draft of the international $\langle I R\rangle$ Framework. The International Integrated Reporting Council.

IRCofSA. (2011). Framework for Integrated Reporting and the Integrated Report Discussion Paper. The Integrated Reporting Committee of South Africa.

Karaburun, G. (2019, Nisan). Muhasebe Kültürü ve Entegre Raporlama Farkındalığı İlişkisi. İzmir Kâtip Çelebi Üniversitesi Sosyal Bilimler Enstitüsü.

Karğın, S., Aracı, H., \& Aktaş, H. (2013, Ocak). Entegre Raporlama: Yeni Bir Raporlama Perspektifi. Muhasebe ve Vergi Uygulamaları Dergisi, 1, 27-46.

Kaya, U., Aygün, D., \& Yazan, Ö. (2016). Yeni Bir Kurumsal Raporlama Yaklaşımı Olarak Entegre Raporlama ve Dünyadaki Uygulama Örnekleri Üzerine Bir Araştırma. Karadeniz Teknik Üniversitesi Sosyal Bilimler Enstitüsü Sosyal Bilimler Dergisi, 85-101.

KING I. (1994). King Report on Corporate Governance for South Africa. Institute of Directors in Southern Africa.

KING II. (2002). King Report on Corporate Governance for South Africa . Institute of Directors in Southern Africa.

KING III. (2009). King Report On Corporate Governance For South Africa. The Institute of Directors in Southern Africa.

KING IV. (2016). KING IV Report. The Institute of Directors in Southern Africa.

Köse, E., \& Çetinel, T. (2017). Kurumsal Ve Entegre Raporlama: Bir Araştırma . Sosyal Bilimler Enstitüsü Dergisi, 155-181.

KPMG. (2011). Integrated Reporting -Performance insight through Better Business Reporting. KPMG.

Küçükgergerli, N. (2017). Entegre Raporlama Endeksi . Türkmen Yayınevi.

Oral, T. (2018). Entegre Raporlamada İçerik Analizi, İnönü Üniversitesi, Sosyal Bilimler Enstitüsü, İşletme Anabilim Dalı, Doktora Tezi.

Petersen, H., \& Svensson, J. (2016). Intellectual Capital Disclosures: The effect of mandatory Integrated Reporting.

Sarığlu, M. (2018). Future of Financial Reporting: Advancements of Integrated Reporting, Dokuz Eylül Üniversitesi, Sosyal Bilimler Enstitüsü, İşletme (İngilizce) Anabilim Dalı Yüksek Lisans Tezi.

Serafeim, G. (2014). Integrated Reporting and Investor Clientele. Working Paper. Harvard Business School.

Sevim, Ş., \& Bayhan, B. (2018). Kamu Sektöründe Entegre Raporlama. Gazi Kitabevi.

Simnett, R., \& Huggins, A. L. (2015). Integrated Reporting And Assurance: Where Can Research Add Value? Sustainability Accounting, Management and Policy Journal.

Solak, B., Gönen, S., \& Rasgen, M. (2017, Mart ). Muhasebe Meslek Mensuplarının Entegre Raporlamaya İlişkin Farkındalık Düzeylerinin Belirlenmesine Yönelik Bir Alan Araştırması. Muhasebe Bilim Dünyası Dergisi.

Solomon, J., \& Maroun, W. (2012). Integrated reporting: the influence of King III on social, ethical and environmental reporting. London: The Association of Chartered Certified Accountants. 
Solstice. (2005). Integrated Reporting - Issues and Implications For Reporters. Solstice Sustainability Works.

Steyn, M. (2014). Organisational benefits and implementation challenges of mandatory integrated reporting Perspectives of senior executives at South African listed companies. Sustainability Accounting, Management and Policy Journal, 5(4), 476-503.

Şimşek, A. (2018). Raporlama Kavramı ve Entegre Raporlamanın Türkiye'deki Uygulama Örnekleri Üzerine Bir Araştırma, Celal Bayar Üniversitesi, Sosyal Bilimler Enstitüsü, İşletme Anabilim Dalı, Yüksek Lisans Tezi.

Tepedelen, A. (2019). Entegre Raporlama ve Entegre Raporlamanın Türk Bankacıllk Sektöründeki Uygulamasına Yönelik Bir Araştırma, Marmara Üniversitesi Bankacılık ve Sigortacılık Enstitüsü.

Topal, Y. (2019, Mayıs). Muhasebe Meslek Mensuplarının Entegre Raporlamaya İlişkin Farkındalık Düzeylerinin Tespiti: Bursa İli Örneği. Sakarya Üniversitesi İşletme Enstitüsü.

UN Global Compact. (2015). The Ten Principles of the UN Global Compact. https://www.unglobalcompact.org/what-is-gc/mission/principles

White, A. L. (2005). New Wine, New Bottles: The Rise of Non-Financial Reporting. Business for Social Responsibility (BSR).

Yıldırım, G., \& Kocamış, T. U. (2018). Entegre Raporlama - Sürdürülebilir ve Daha İi Bir Yönetim için Entegre Raporlama. Türkmen Kitapevi.

Yılmaz, N. D. (2016). Entegre Raporlamanın Yatırımcılar Açısından Analizi ve Entegre Yatırım Analizi Algoritması, Dumlupınar Üniversitesi, Sosyal Bilimler Enstitüsü, İşletme Anabilim Dalı, Yüksek Lisans Tezi.

Yücel, E. (2018). Entegre Raporlama - Kurumsal Sürdürülebilirlik Kapsamında Kurumsal Raporlamanın Gelişimi. Dora .

Yüksel, F. (2017). Entegre Raporlama. Ekin Yayınevi.

Yüksel, F., \& Aracı, H. (2017). Entegre Raporlama, Türk İşletmelerinin Entegre Raporlamaya Bakışı Üzerine Bir Araştırma. Yönetim ve Ekonomi, 24(3), 741-757. 